\title{
Agricultural water demand with its cost
}

\section{Opinion}

In Taiwan, we have the annual precipitation $2,504 \mathrm{~mm}$ and it is corresponding to 9 billion cubic meters water. Because of the steep slope watershed with uncertain rainfall both on time and space, the effective water volume for good distribution on utilization for people's livelihood, industrial and agricultural demands will become trouble. In this article we just discuss on agricultural water demand with its cost, this cost is not including the raw water cost because it is another serious issue we will reinforce future. There 17 irrigation associations in Taiwan (Figure 1).

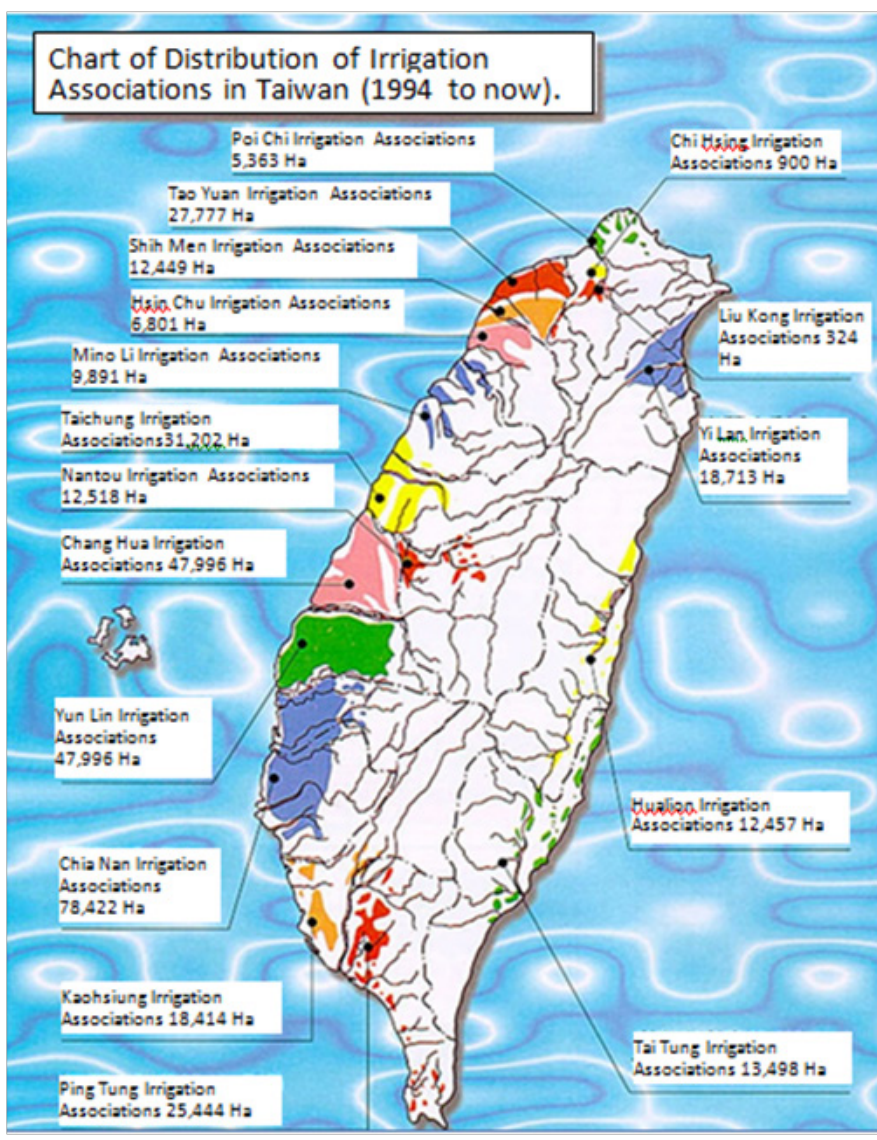

Figure I Chart of distribution of irrigation association in Taiwan (from 1994 to now).

The research results as in Table 1 . In which data of the quantities of water consumption, rice production, pumping electricity fee and staff costs are supplied by government while else fee are collected from the real field data and analyzed based on the agricultural and economic methods. ${ }^{1-5}$ Due to the steep terrain, the riverbed in Taiwan is greatly reduced. In the case of rain, the flash floods are soaring and flooding, and the drought is bottoming out. The lack of water is the only way to build a reservoir dam to achieve effective river management. Water, increase the use of water such as irrigation, power generation, industrial and public water supply, and combine flood control and disaster relief, increase agricultural production, and develop tourism. In the early years of Taiwan, there were reservoirs.
Volume 2 Issue 6 - 2018

\author{
Edward Ching-Ruey LUO,' Chung-Wen LIU² \\ 'Assistant Professor of National Chi-nan University, Taiwan \\ ${ }^{2}$ Deputy Chief Engineer,Water Resources Agency, MOE, Taiwan
}

Correspondence: Edward Ching-Ruey LUO, 227 Gan-Cherng Street, 40843 Nan-tun District, Taichung Taiwan, Taiwan, Tel +886-910-549999, Email edvvard.luo@msa.hinet.net

Received: August 18, 2018 | Published: December 03, 2018

By 2010, there were 258 reservoirs and dams in Taiwan, with a total storage capacity of 2,130.7 million cubic meters and an effective capacity of 1,999.22million cubic meters], the largest in Zengwen Reservoir, with a total capacity of 71.27 million cubic meters and an effective capacity of 475.55 million cubic meters. Others are located in the outlying islands, one in Taitung County, eight in Wuhu County, 13 in Jinmen County and seven in Lianjiang County (Figure 2).

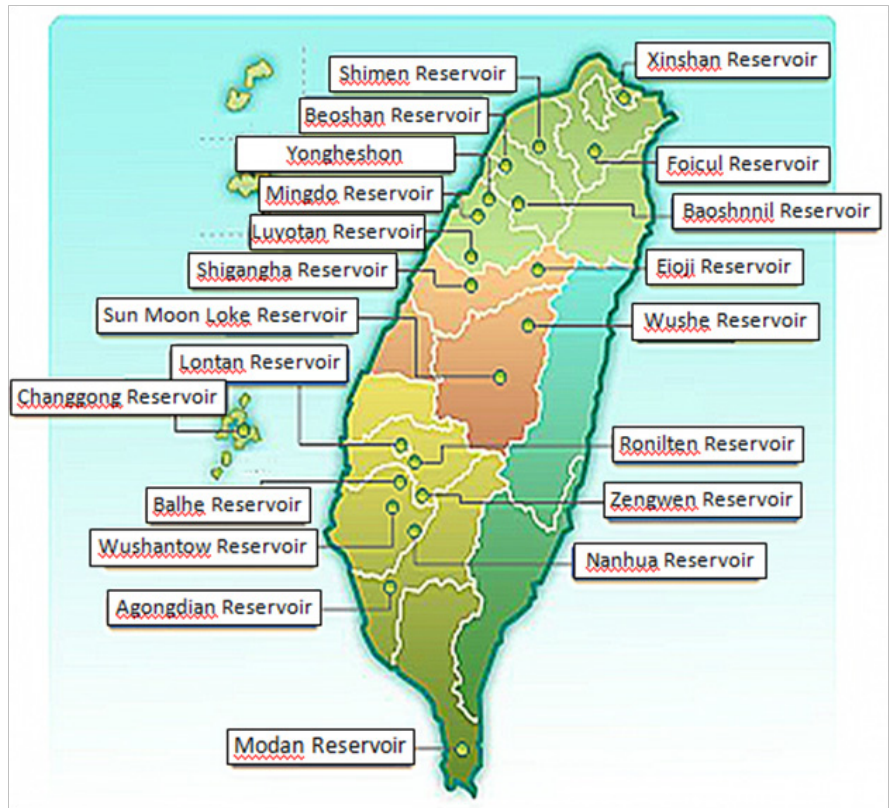

Figure 2 Reservoirs of Taiwan.

Taiwan reservoir management related units include the Water Resources Department of the Ministry of Economic Affairs (North, Central and Southern Water Resources Bureau), Taiwan Water Supply Company, Taiwan Power Company, Taipei City Government Taipei Jade Reservoir Administration, Miaoli County Farmland Water Conservancy Association, and Jianan County Farmland Water Conservancy Will wait for the unit, the jurisdiction of the Republic of China, Total water discharge from reservoirs includes consumable and non-consumptive water. Consumable water consumption includes irrigation, production and industrial water. In the whole year of 1990, the reservoir supplier counted 4.79billion cubic meters. Nonconsumption water refers to power generation. Among them, the supply part of the reservoir is 9.48 billion cubic meters. In the past 
90 years, the water discharge of the reservoir was 11.9 billion cubic meters. Because of the repeated use of the two, the total water discharge is not the sum of the two.

For analyzing the raw water cost $(\mathrm{C})$, the effective volume $(\mathrm{X})$ and the year of construction (T) of each reservoir will be the key factors. The regressing formula could be the form as following, and it is necessary to define the coefficients with the real data with statistics:

$$
\ln C=a+b \ln X+\operatorname{cln}(T-1911)
$$

Referencing Figure $2 \&$ Table 2, the coefficients of a, b, and c are: $\mathrm{a}=-15.0211, \mathrm{~b}=0.8415$, and $\mathrm{c}=4.00297$ with $R^{2}=0.8114$

Here C: the annual Reservoir Cost in Million NT; X: the Annual Operation Water Volume of Reservoir; T: the Established Year of Reservoir. In Eq. (1) we can clearly see that the water resources has the time and space characteristics and it is limited. The later the building and the larger the scale, the higher the cost.

Table I First period rice harvest (March to June total I22 days) with its corresponding fundamental cost analysis for each irrigation association

\begin{tabular}{|c|c|c|c|c|c|c|c|}
\hline $\begin{array}{l}\text { Irrigation } \\
\text { Association }\end{array}$ & $\begin{array}{l}\text { Farming } \\
\text { area(ha) }\end{array}$ & $\begin{array}{l}\text { Water } \\
\text { consumption } \\
\text { (Tons) }\end{array}$ & $\begin{array}{l}\text { Rice } \\
\text { production } \\
\text { (kgs) }\end{array}$ & $\begin{array}{l}\text { Pumping } \\
\text { electricity fee } \\
\text { (USD/Ton) }\end{array}$ & $\begin{array}{l}\text { Staff costs } \\
\text { (USD/Ton) }\end{array}$ & $\begin{array}{l}\text { Else fee } \\
\text { (USD/Ton) }\end{array}$ & $\begin{array}{l}\text { Total fee } \\
\text { (USD/Ton) }\end{array}$ \\
\hline Yilan & 15,175 & $254,911,888$ & $71,493,000$ & -- & 0.02 & 0.19 & 0.221 \\
\hline Pewichi & 1,063 & $93,1 \mid 4,518$ & $4,784,000$ & -- & 0.19 & 0.032 & 0.084 \\
\hline Taoyuan & 22,645 & $2,089,897,863$ & $107,807,000$ & -- & 0.017 & 0.026 & 0.077 \\
\hline Shihmen & 10,516 & $731,551,594$ & $41,097,000$ & -- & 0.018 & 0.025 & 0.079 \\
\hline Hsinchu & 6,445 & $95,6|2,86|$ & $30,6 \mid 4,000$ & -- & 0.02 & 0.053 & 0.281 \\
\hline Miaoli & 8,490 & $|28,74|, \mid 84$ & $46,865,000$ & 0.001 & 0.021 & 0.095 & 0.34 \\
\hline Taichung & 29,249 & $5,398,536,269$ & $150,632,000$ & -- & 0.017 & 0.02 & 0.055 \\
\hline Nantou & 9,522 & $262,658,880$ & $48,195,000$ & -- & 0.019 & 0.037 & 0.177 \\
\hline Changhua & 37,308 & $4 \mid 4,189,274$ & $211,677,000$ & -- & 0.022 & 0.063 & 0.417 \\
\hline Yunlin & 25,108 & $179,253,389$ & $135,585,000$ & 0.005 & 0.036 & 0.153 & 0.685 \\
\hline Chianan & 33,588 & $2,470,311,994$ & $217,589,000$ & -- & 0.018 & 0.027 & 0.103 \\
\hline Kaoshiung & 7,872 & $1,638,480,125$ & $46,528,000$ & -- & 0.177 & 0.032 & 0.068 \\
\hline Pingtung & 8,806 & $219,835,613$ & $48,433,000$ & 0.003 & 0.022 & 0.056 & 0.255 \\
\hline Taitung & 4,716 & $264,831,999$ & $22,165,000$ & -- & 0.019 & 0.037 & 0.11 \\
\hline Hualian & 6,513 & $468,146,333$ & $28,006,000$ & -- & 0.018 & 0.028 & 0.085 \\
\hline Chishing & 860 & $58,891,882$ & $4,386,000$ & -- & 0.021 & 0.182 & 0.252 \\
\hline Liukong & 216 & $5,272,790$ & 756,000 & 0.005 & 0.08 & 0.171 & 0.349 \\
\hline
\end{tabular}

I. Rice Unit Cost(80\$) $\square 0.65$ USD/kg

2. Staff costs $=($ annual fee $) \times\left(\frac{122}{365}\right) \div$ Water consumption

3. Else fee $=\{($ Pipeline depreciation fee $)+($ Pipeline equipment maintenance fee $)+($ Irrigation fee $)+($ Service fee $)+($ Research fee $)+($ fee of management $)+($ Miscellaneous $)\} \times\left(\frac{122}{365}\right) \div$ Water consumption

4. Total fee $=\{($ Rice production $) \times 0.65\} \div$ Water consumption + Pumping electricity fee + Staff costs + Else fee.

$\square$ The mean agricultural water fundamental cost is $0.212 \mathrm{USD} /$ Ton with maximum value $0.685 \mathrm{USD} /$ Ton (Yunlin) and minimum value $0.055 \mathrm{USD} /$ Ton(Taichung), all the cost is without consideration of raw water cost, it means the civil engineering construction cost is not yet included. 
Table 2 Unit primary water cost with different reservoirs or weirs in Taiwan

\begin{tabular}{|c|c|c|c|c|c|c|c|}
\hline \multirow{2}{*}{$\begin{array}{l}\text { Name of } \\
\text { reservoir } \\
\text { (Weir) }\end{array}$} & \multirow{2}{*}{$\begin{array}{l}\text { Established } \\
\text { year }\end{array}$} & \multicolumn{2}{|c|}{$\begin{array}{l}\text { Total cash ( } 10 \text { thousand } \\
\text { NT\$) }\end{array}$} & \multirow[t]{2}{*}{$\begin{array}{l}\text { Annual cash (10 } \\
\text { thousand NT } \$) \\
(2)=(1) \times 9.55 \%\end{array}$} & \multirow[t]{2}{*}{$\begin{array}{l}\text { Annual water } \\
\text { supply (3) (10 } \\
\text { thousand tons) }\end{array}$} & \multirow{2}{*}{$\begin{array}{l}\text { Unit primary } \\
\text { water cost }(2) /(3) \\
\text { (NT\$/Ton) }\end{array}$} & \\
\hline & & $\begin{array}{l}\text { Cash of } \\
\text { Established } \\
\text { year }\end{array}$ & $\begin{array}{l}\text { (I)Cash } \\
\text { flow of } \\
\text { |99| }\end{array}$ & & & & \\
\hline Shimen & 1964 & 318,300 & $\mathrm{I}, 099,408$ & 104,933 & 68,100 & 1.54 & \\
\hline Mingdo & 1970 & 21,735 & 71,727 & 6,850 & 3,329 & 2.06 & \\
\hline Zengwen & 1973 & 603,842 & $|, 28|, \mid 72$ & 122,352 & 73,049 & 1.67 & \\
\hline Xinshan & 1979 & 24,690 & 30,221 & 2,886 & 542 & 5.32 & \\
\hline Fengshan & 1984 & 83,000 & 89,267 & 8,525 & $|5,43|$ & 0.55 & \\
\hline Beoshan & 1985 & 63,000 & 69,048 & 6,594 & 1,665 & 3.96 & \\
\hline Ronilten & 1987 & 156,000 & 166,717 & $|5,92|$ & 4,278 & 3.72 & \\
\hline Foicul & 1987 & $\mathrm{I}, 145,464$ & $\mathrm{I}, \mathrm{I} 45,464$ & $|09,39|$ & 20,800 & 5.26 & \\
\hline Luyotan & 1997 & $1,060,000$ & $1,060,000$ & 101,230 & 30,483 & 3.32 & \\
\hline Nanhua & 1993 & 995,700 & 995,700 & 95,089 & 29,200 & 3.26 & \\
\hline Modan & 1995 & 780,000 & 780,000 & 74,490 & 3,710 & 20.08 & \\
\hline Chichi (Weir) & 1999 & $3,265,000$ & $3,265,000$ & 311,808 & 47,400 & 6.58 & \\
\hline Baoshnnil & 1998 & $1,860,000$ & $\mathrm{I}, 860,000$ & 177,630 & 7,416 & 23.95 & \\
\hline Menueng & 2001 & $5,330,000$ & $5,330,000$ & 509,015 & 40,600 & 12.54 & * \\
\hline Geinmin & 2001 & $3,050,000$ & $3,050,000$ & 291,275 & 24,000 & 12.14 & * \\
\hline Coast Res. & 2001 & $4,500,000$ & $4,500,000$ & 429,750 & 30,000 & 14.32 & * \\
\hline $\begin{array}{l}\text { Da-ching } \\
\text { (Weir) }\end{array}$ & 2001 & 400,000 & 400,000 & 38,200 & 5,000 & 7.64 & $*$ \\
\hline Kaoping & & & & & & & \\
\hline $\begin{array}{l}\text { Downstream } \\
\text { (Weir) }\end{array}$ & 1996 & 500,000 & 500,000 & 47,750 & 10,000 & 4.78 & \\
\hline
\end{tabular}

$*$ Planning IUSD=30NT\$

\section{Acknowledgments}

None.

\section{Conflicts of interest}

The author declares that there are no conflicts of interest

\section{References}

1. OECD. Agricultural Water Pricing: United States. Surface water characterization \& utilization in the Middle East. Respectively Exemplified By Nahal Eshtemoa (Wadi Samoa) \& The Shiqma-Besor (Wadi Gaza). 2010;1-27.
2. Mohammed Ziaul Haider. Cost-Benefit Analysis on Shrimp Aquaculture versus Agriculture and other Natural Resource Management (NRM). Project: TA - 6422 (REG): Mainstreaming Environment for Poverty Reduction. 2012.

3. Ashley Hemping. Economic Analysis of Reverse Osmosis Desalination of Water for Agricultural Irrigation applications. California Polytechnic State University. 2011;1-59.

4. Gerald Atampugre. Cost and Benefit Analysis of the adoption of Soil and Water Conservation Methods, Kenya. International Journal of Scientific and Research Publications. 2014;4(8):1-14.

5. Sales and Marketing Group. Coping with Water Scarcity-- An Action Framework for Agriculture and Food Security. FAO Water Reports. 2008. 